\title{
Conservation of indigenous cattle genetic resources in Southern Africa's smallholder areas: turning threats into opportunities - A review
}

\author{
G. B. Nyamushamba', C. Mapiye ${ }^{2}$, 0. Tada ${ }^{3}$, T. E. Halimani ${ }^{4}$, and V. Muchenje ${ }^{1, *}$
}

\author{
* Corresponding Author: V. Muchenje \\ Tel: +27-40-602-2059, Fax: +27-84-422-1487, \\ E-mail: vmuchenje@ufh.ac.za \\ 'Department of Livestock and Pasture Science, \\ University of Fort Hare, Alice 5700, South Africa \\ ${ }^{2}$ Department of Animal Sciences, Faculty of \\ AgriSciences, Stellenbosch University, Matieland \\ 7602 , South Africa \\ ${ }^{3}$ Department of Animal Production and Technology, \\ Chinhoyi University of Technology, Chinhoyi , \\ Zimbabwe \\ ${ }^{4}$ Department of Animal Science, University of \\ Zimbabwe, Harare, Zimbabwe
}

Submitted Jan 8, 2016; Revised Feb 15, 2016; Accepted Mar 18, 2016

\begin{abstract}
The current review focuses on characterization and conservation efforts vital for the development of breeding programmes for indigenous beef cattle genetic resources in Southern Africa. Indigenous African cattle breeds were identified and characterized using information from refereed journals, conference papers and research reports. Results of this current review reviewed that smallholder beef cattle production in Southern Africa is extensive and dominated by indigenous beef cattle strains adaptable to the local environment. The breeds include Nguni, Mashona, Tuli, Malawi Zebu, Bovino de Tete, Angoni, Landim, Barotse, Twsana and Ankole. These breeds have important functions ranging from provision of food and income to socio-economic, cultural and ecological roles. They also have adaptive traits ranging from drought tolerant, resistance to ticks and tick borne diseases, heat tolerance and resistance to trypanosomosis. Stakeholders in the conservation of beef cattle were also identified and they included farmers, national government, research institutes and universities as well as breeding companies and societies in Southern Africa. Research efforts made to evaluate threats and opportunities of indigenous beef cattle production systems, assess the contribution of indigenous cattle to household food security and income, genetically and phenotypically characterize and conserve indigenous breeds, and develop breeding programs for smallholder beef production are highlighted. Although smallholder beef cattle production in the smallholder farming systems contributes substantially to household food security and income, their productivity is hindered by several constraints that include high prevalence of diseases and parasites, limited feed availability and poor marketing. The majority of the African cattle populations remain largely uncharacterized although most of the indigenous cattle breeds have been identified.
\end{abstract}

Keywords: Indigenous Cattle Breeds; Characterisation; Socio-Eco-Cultural Roles; Household Food Security

\section{INTRODUCTION}

The global livestock sector is characterized by a growing dichotomy between livestock kept extensively by a large number of smallholders and pastoralists (600 million) in support of food security and livelihoods, and those kept in intensive commercial production systems [1,2]. In Southern Africa, over $90 \%$ of animal keepers are classified as smallholders and $75 \%$ of the farm animals which largely consists of indigenous breeds belong to the smallholder sector [3]. For example, indigenous cattle breeds such as Nguni, Mashona, Tswana, and Tuli are critical components of smallholder beef production in Southern Africa. Currently southern African region is richly endowed with many indigenous beef cattle breeds such as the Afrikaner, Tuli, Tswane, Barotse, Boran, Mashona, Nkone, Angoni, and Nguni/Landim (Mozambique), but is threatened by increased uncontrolled crossbreeding with exotic genotypes like the Hereford, 
Santa Getrudis, Aberdeen Angus and Simmental [4]. For example, in the case of the emerging sector of South Africa nondescript/crossbred cattle make up $66.4 \%$ of herds [5]. Although the purpose of crossbreeding in beef cattle is partly to combine breed differences and partly to make use of heterosis to improve production, it has threatened the exisistence of the indigenous cattle genotypes in Southern Africa [6,5]. These indigenous breeds among others are not well characterized or described, and are seldom subject to structured breeding programmes to improve performance. More importantly, these indigenous animal genetic resources are in a continual state of decline due to indiscriminate crossbreeding and institutional policies that support use of high producing exotic breeds in the smallholder areas [7]. The erosion of indigenous cattle genetic resources is currently a cause for concern in Southern Africa as they are an integral contributor of food, agricultural power, agrarian culture and heritage, and genetic biodiversity in the region $[8,5]$. Overall, animal genetic diversity enables farmers to select stocks or develop new breeds in response to changing conditions, including climate change, new or resurgent disease threats, new knowledge of human nutritional requirements, and changing market conditions or changing societal needs [2].

Southern Africa's climate and production environment vary widely and include numerous harsh environments that combine high temperatures, droughts and floods and epidemic of disease and parasites related to climate change [3]. These conditions give the indigenous breeds a competitive edge over exotic breeds that have been raised in temperate climates. Given the current harsh production circumstances and potential for significant future changes in production conditions and production goals, it is crucial that the value provided by indigenous cattle genetic diversity is secured through characterisation, conservation and development of breeding programmes. It is important to note that development of strategies for characterisation and conservation of indigenous cattle requires consideration of multiple factors including biology of animals, agroecology of the environment, production system of the animals, purpose of rearing and affordability of the owners duly to be addressed [9]. Thus, characterization and conservation of indigenous cattle breeds, including their unique products, should be accorded high priority in the Southern African region. That is essential in designing conservation programmes for indigenous cattle and could strengthen the future position of the indigenous cattle breeds in the expected new smallholder cattle production systems and changing production environments. To design successful conservation programmes for indigenous cattle breeds, it is essential for the stakeholders to prepare strategic long-term plans to accommodate the challenges of limited resources such as land, feed, labour and capital. The current review provides an overview of efforts made to characterize, conserve and develop breeding programmes for indigenous beef cattle genetic resources in Southern Africa and discusses threats and opportunities for the development of breeding and conservation programmes in the smallholder areas.

Distribution and status of indigenous beef cattle breeds in Southern African smallholder areas

Currently, about 180 breeds of cattle have been recognized in sub-Saharan Africa [10,11]. The number includes 150 breeds of indigenous cattle of which $25 \%$ are found in Southern Africa. The distribution of the indigenous beef cattle in sub-Saharan Africa is shown in Figure 1. Rewe et al [12] reported that Sanga cattle (Bos taurus Africanus) breeds such as Nguni, Tuli, Barotse, Tswana, Tonga, and Mashona are the dominant indigenous beef cattle breeds found in Southern Africa. Phenotypically humped, zebu cattle (Bos indicus) breeds such as Malawi Zebu and Angoni are also common [13]. Of these breeds, $65 \%$ to $90 \%$ of the cattle are found in smallholder areas (Table 1). The genetic distinctiveness between these cattle breeds, however, remain largely unknown. In that regard, it may be more appropriate to talk about African cattle populations or ecotypes instead of breeds. A breed is a homogenous group of livestock which are phenotypically unique from other groups or subpopulations of the same species $[9,15]$.

Overall, the purity of indigenous cattle breeds is under threat due to crossbreeding and institutional polices that support the use of imported breeds $[14,10,8]$ Pure Nguni cattle numbers in South Africa for example, declined from 1,800,000 in 1992 to 9,462 in 2003 [7]. The situation is aggrevated by lack of records and uncontrolled mating systems practiced in the smallholder areas [10], which, in most cases, promote inbreeding. In addition, both planned and indiscriminate crossbreeding between indigenous and imported breeds generated non-descript/crossbred cattle, which are now dominant in most Southern African smallholder areas $[16,17]$. For example, in the case of the emerging sector of South Africa non-descript/crossbred cattle constitute about two-thirds of the cattle population in this sector [14]. Although, African cattle genetic diversity remains large, cattle populations or breeds continue to face extinction. According to [10], 22\% of African cattle breeds have already become extinct in the last century and $32 \%$ of indigenous African cattle breeds are in danger of extinction [12]. Moreover, some breeds that are critically endangered have fewer than 1,000 animals, including South African sanga breeds such as the Nkone, Pedi, and Shangan [143]. According to [13], extensive crossbreeding, replacement with exotic breeds, and social and environmental disasters have placed these indigenous bovines at risk of extinction.

Extension messages in the colonial era created the perception that, for beef production, indigenous cattle breeds are inferior to imported breeds because of their small-frame [12]. To compensate for the perceived lower beef production potential of indigenous cattle, crossbreeding of these cattle with exotic breeds, was commonly practiced, with minimal within breed selection 


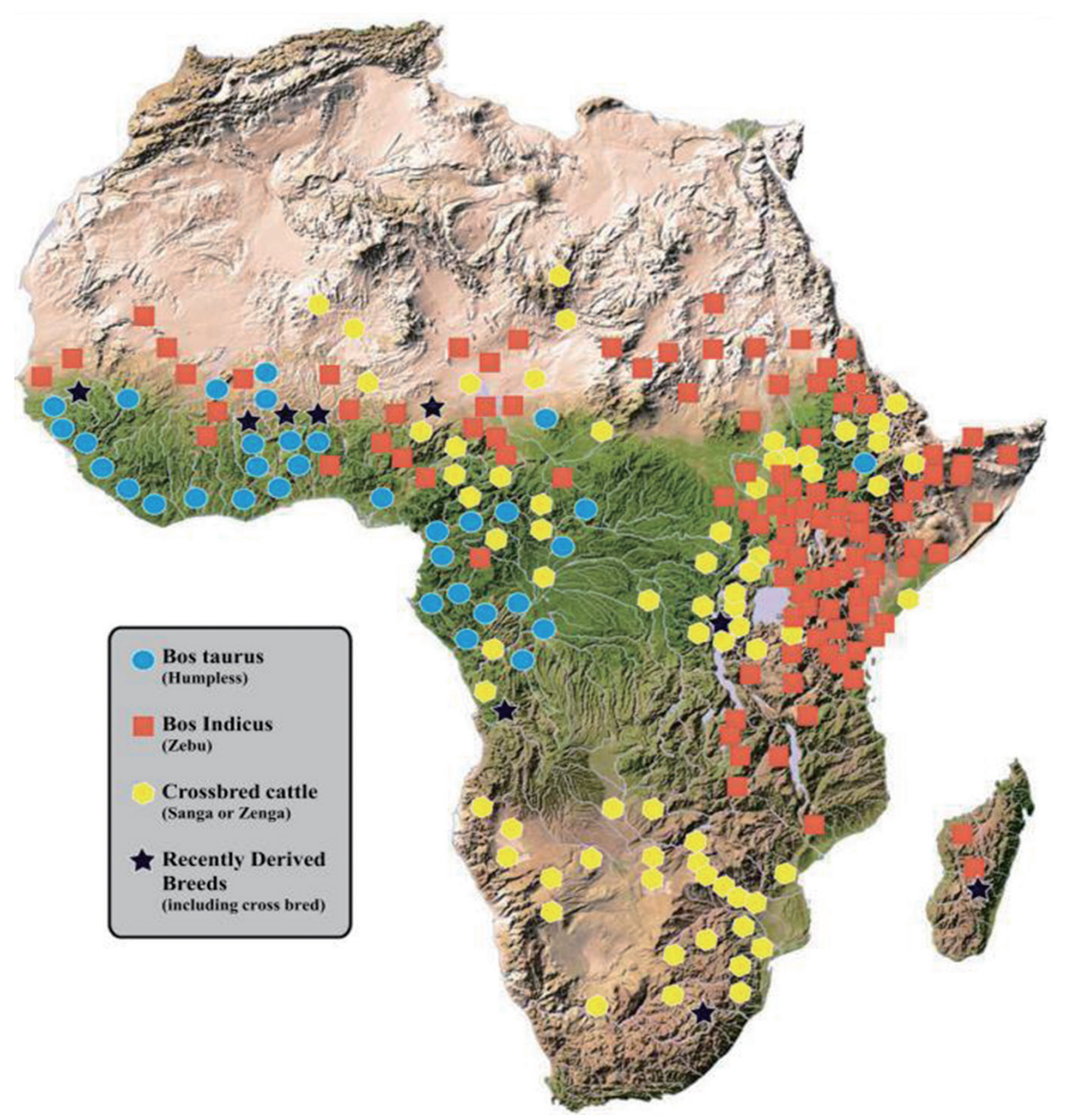

Figure 1. Distribution of indigenous and cross bred cattle in sub-Saharan Africa. Adapted from Mwai et al [63].

program for the indigenous breeds [13]. The end result was a continuous erosion and loss of indigenous cattle diversity. It is, therefore, important to comprehend the role of indigenous cattle in the smallholder areas and characterize them to objectively inform their utilization and conservation before they disappear [18].

The economic value of indigenous beef cattle in smallholder

Table 1. Beef cattle populations in SADC and the proportion in the smallholder areas

\begin{tabular}{lccc}
\hline Country & Population $^{1)}$ & $\begin{array}{c}\text { Proportion in } \\
\text { smallholder areas }\end{array}$ & Sources \\
\hline Botswana & 2.3 & 0.88 & {$[156]$} \\
Malawi & 1.2 & 0.90 & {$[157]$} \\
Mozambique & 1.2 & - & {$[158]$} \\
Namibia & 2.4 & - & {$[159]$} \\
South Africa & 14.1 & 0.67 & {$[160,95]$} \\
Zambia & 2.5 & 0.94 & {$[161]$} \\
Zimbabwe & 5.2 & 0.91 & {$[94]$} \\
\hline
\end{tabular}

\footnotetext{
1) Populations are in millions.
}

areas

Studies by [19] and [8] revealed that smallholder farmers keep beef cattle for multiple purposes. Rural households depend on cattle for meat and milk as sources of food and income through sales and for by-products such as horns and hides [19]. The hides are further processed to make carpets, seat covers, harnessing ropes, drumbeats and hats for the spirit mediums [20,21]. Cattle also provide dung for manure, floor polish/seal and fuel [16], either in the form of dried dung cakes or via the production of biogas. In addition, cattle are a source of draught power for cultivation of crops and transport of goods in smallholder areas $[22,9]$. Cattle are an inflation-free form of banking for resourcepoor people and can be sold to meet family financial needs such as school fees, medical bills, village taxes and household expenses $[23,24]$. They are a source of employment, collateral and insurance against natural calamities. More importantly, indigenous cattle are valuable reservoirs of genes for adaptive and economic traits, providing diversified genetic pool, which can help in meeting future challenges resulting from changes in production sources and market requirements [8-25]. 
Socio-cultural functions of indigenous cattle

Socio-cultural functions of cattle include their use as bride price (lobola) and to settle disputes (as fine) in smallholder areas [26,19]. Cattle are reserved for special ceremonial gatherings such as marriage feasts, weddings, funerals, circumcision and ancestral communion (e.g bira- an all-night ritual, performed to call on ancestral spirits for guidance and intercession) $[8,9]$. Cattle are given as gifts to visitors and relatives, and as starting capital for youth and newly married man [21]. They are used to strengthen relationships with in-laws and to maintain family contacts by entrusting them to other family members [23]. Cattle play an important role in installation of spirit mediums, exorcism of evil spirits and are given as sacrificial offerings to appease avenging spirits $[9,16]$. Some farmers keep cattle for prestige and pleasure [22]. The relative importance of each of the cattle functions vary with farmers' objectives, production system, rangeland type, region and socio-economic factors such as gender, marital status, age, education and religion of the keepers $[26,24,16]$. Efforts to characterise, conserve and develop breeding programs should, therefore, emphasize the understanding of farmers' objectives, and socio-demographic factors. From this knowledge, constraints and opportunities faced by resource poor smallholder cattle farmers can be identified and sustainable developmental strategies formulated [23].

\section{Ecological values of indigenous cattle breeds}

Livestock serves multiple purposes in supporting the ecological and biological wellbeing of our planet. For smallholder farmers in mixed crop-livestock production systems, securing a supply of manure can be among the most important reasons for keeping animals. For example, a study conducted by [27] in the Gambia, indicated that among mixed farmers with fewer than ten cattle, manure supply ranked as the second most important reason for keeping cows and third for keeping bulls. Among farmers with larger herds, manure supply was reported to be the most important livestock function. The significance of livestock manure in crop production is noted above. Manure plays a key role in crop production by providing essential crop nutrients [26-28]. However, dunging also affects the health of grassland soils. In grazing systems, the effects of dunging have to be considered along with the effects of grazing and trampling [29]. Outcomes depend on the particular characteristics of the ecosystem and on the type of grazing management practised. Soil health is fundamental not only to the productivity of grazing systems, but also to their roles in carbon sequestration and water cycling. Many rangelands have suffered soil compaction and erosion as a result of livestock grazing. However, appropriately managed grazing can also contribute to improving soil health $[29,30]$. In many countries, grazing livestock play a significant role in the creation and maintenance of fire breaks and hence in reducing the spread of wildfires $[31,32]$. They can also contribute to reducing the risk of avalanches [33].
Kugler and Broxham [34] reported that cattle play an important role in biodiversity conservation such as weed and fire control, maintenance of biodiversity and carbon sequestration. It is important that the use of livestock is properly managed and regularly monitored in order to make sure that both the cattle and the eco-system are healthy [34]. Livestock make their most important contribution to total food availability when they use feed sources that cannot directly be eaten by humans [35]. This occurs, for example, when livestock graze areas that cannot be used for crop production, when they eat crop residues such as straw and stovers, by-products of food processing and waste food products that are no longer edible to humans. These cases can be contrasted with those in which animals are fed on feeds that could otherwise be used directly by humans (e.g. grains). Food production clearly falls within the provisioning category of ecosystem service. However, in some cases, the removal of unwanted plant material also constitutes a service. In grazing systems, the benefits concerned may relate to the removal of plant material that creates a fire hazard or the control of invasive species. In mixed systems, livestock may be used to control weeds (e.g. on fallow land) or in the management of crop residues [36].

\section{CHARACTERISATION AND THE ADAPTIVE TRAITS OF INDIGENOUS BEEF CATTLE BREEDS}

Indigenous cattle breeds in Southern Africa have unique morphological features which distinguishes them from other cattle (Table 2). These include horn shape and size (e.g. Ankole and Kuri cattle: $[11,37,38]$ and coat colour (i.e Nguni) as shown in Figure 2. In addition to physical features, non-visible traits such as disease resistance, climatic stress resistance and productivity traits also differ among breeds. These characteristics are largely the result of natural and human selection [38].

\section{Adaptability traits of indigenous beef cattle}

Adaptability of an animal can be defined as the ability to survive and reproduce within a defined environment or the degree to which an organism, population or species can become or remain adapted to a wide range of environments by physiological or genetic means [39]. The level of production achieved by a particular genotype in harsh environments depends on the contribution and expression of many different traits which may be partitioned into those directly involved with production such as feed intake, digestive and metabolic efficiency, measured in the absence of environmental stress and those involved with adaptation such as low maintenance requirements, heat resistance, parasite and disease resistance [40].

\section{Drought tolerant}

According to [41] indigenous beef cattle have an advantage for 


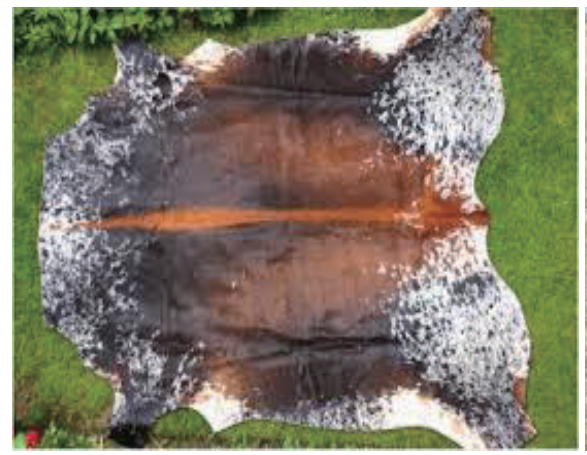

A

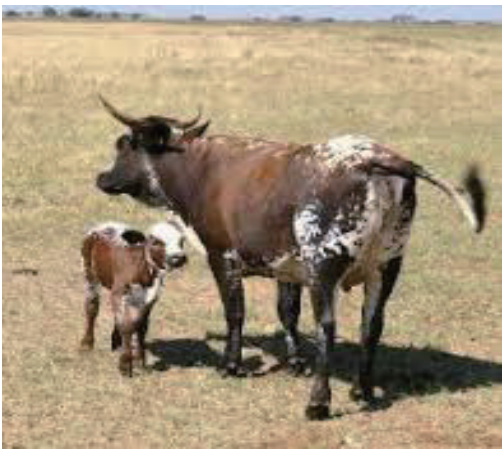

B

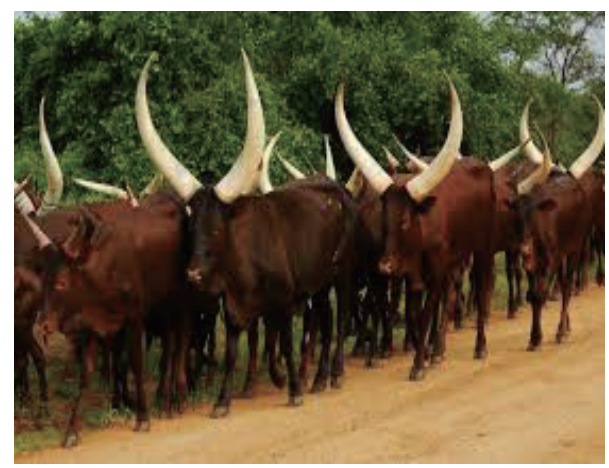

C

Figure 2. Morphological features of indigenous cattle. A, Multi coloured Skin from Nguni cattle; B, Multi coloured Nguni cow and calf; C, Elongated horns of Ankole cattle.

their natural attributes of better feed utilization in case of poor forage conditions, or hardiness and survival in extreme climate changes. High daily temperatures and soils in the arid regions influence the type, quality and quantity of forages available for livestock [42]. For example, the Nguni, a major indigenous cattle breed in Southern Africa, is small to medium sized breed and adapts well to the harsh environments of South Africa's smallholder areas where droughts are periodic and dry season nutrition $[43,44]$. To cope with drought and forage seasonality, Nguni cattle have low nutrient requirements for maintenance, and excellent walking ability, which enables it to walk long distances in search of grazing and water $[45,46]$. Nguni also has good selective grazing and browsing abilities, which enables it to obtain optimal nutrition from the available natural vegetation, thus enabling it to survive under conditions that bulk grazers such as the European cattle breeds would find extremely testing [47;48]. Although it is small to medium sized, has meat quality characteristics that compare favourably with European beef breeds $[47,49]$. The smaller size of the indigenous breeds with lower growth rates and milk production levels and high reproductive performance have also been considered as adaptation to the availability of low quantity and quality forages $[43,50,51]$. The amount of nutrients required to maintain an animal to undertake day to day physiological processes neces- sary for survival (such as tissue building and repair) depends among others on body size $[43,52]$. The small size of the indigenous breeds is, therefore, a result of natural synchronization of the genotype with available feed resources. In these marginal production areas where feed resources are limiting, both in quantity and quality, the large sized breeds are more likely to suffer reproductive impairments than the smaller breeds.

\section{Resistance to ticks}

Tick infestation is one of the major problems that farmers face [53], causing economics losses in the cattle industry $[54,55]$. Africa loses $\$ 160$ million in tick and tick-borne diseases' (TBD) related to cattle deaths annually [56,57]. African Bos indicus cattle are believed to be more resistant to infestation by cattle ticks compared to taurine animals [58]. Several studies have been conducted to determine the resistance of Nguni cattle to ticks under both controlled $[59,49]$ and uncontrolled conditions [60-62]. Under both conditions the Nguni breed had lower tick loads than exotic breeds and non-descript crossbreds. The beef cattle breeds and their level of resistance to specific tick species are shown below (Table 3 ).

Mwai et al [63] revealed that, the Tswana cattle from Botswana are also resistant to heavy tick challenges. These findings concur with [11] who also studied the same breed. [4] reported that 
Table 2. Major characteristics of indigenous beef cattle breeds in Southern Africa

\begin{tabular}{|c|c|c|c|c|}
\hline Breed & Location & Other phenotypic characteristics & Current breeding activities & Sources \\
\hline Nguni & $\begin{array}{l}\text { South Africa, } \\
\text { Zimbabwe, } \\
\text { Lesotho, } \\
\text { Swaziland, } \\
\text { Namibia }\end{array}$ & $\begin{array}{l}\text { Multi-coloured beef, Glossy red and white coat well pigmented and multi-coloured } \\
\text { skin, Short haired, High fertility, Has potential for milk production, Mature } \\
\text { bull weigh } 430 \text { to } 680 \mathrm{~kg} \text { and Mature cow weigh of } 225 \text { to } 450 \mathrm{~kg} \text {, Excellent } \\
\text { resistance to ticks and tick borne diseases, Disease incidence and mortality are } \\
\text { low, draught animal. }\end{array}$ & Breeding activity present & $\begin{array}{l}{[143,107]} \\
{[49,20,94]}\end{array}$ \\
\hline Mashona & Zimbabwe & $\begin{array}{l}\text { Black and red mostly poled, Have compact body conformation, Long tail that } \\
\text { touches the ground, Mature weight of } 275 \text { to } 350 \mathrm{~kg}\end{array}$ & Breeding activity present & [17] \\
\hline Tuli & $\begin{array}{l}\text { Zimbabwe, } \\
\text { South Africa }\end{array}$ & $\begin{array}{l}\text { Have smooth coated, light coloured, but full pigmented Tuli is well fitted out } \\
\text { to survive and prosper in the hottest environment, Docile, naturally polled; pri- } \\
\text { marily for beef production. In conformation the Tuli is large-framed, rounded, } \\
\text { well-balanced, with emphasis on a strong back and well-fleshed hindquarter. }\end{array}$ & Breeding activity present & [162] \\
\hline Malawi Zebu & Malawi & $\begin{array}{l}\text { A compact animal with a characteristically beef-type conformation, The head } \\
\text { is short with a straight or slightly convex profile. The horns are generally short } \\
\text { and wide at the base and sometimes curve slightly forward or backward. Lyre- } \\
\text { shaped horns are occasionally seen, as are polled animals. The ears are short } \\
\text { and non-pendulous. Predominant whole colours of the Malawi zebu are black } \\
\text { and red, the latter often with black points, but a wide range occurs. Have high } \\
\text { reproductive potential. }\end{array}$ & Breeding activity present & [17] \\
\hline Bovino de Tete & Mozambique & $\begin{array}{l}\text { White, cream and thick gray in coat colour, Some are Brown, red, white, black, } \\
\text { dark red in coat colour and have a reduced hump. Have long and lateral black } \\
\text { horns. }\end{array}$ & - & [17] \\
\hline Angoni & $\begin{array}{l}\text { Zambia, } \\
\text { Mozambique }\end{array}$ & $\begin{array}{l}\text { Coat colour varies and may be red, brown, black, red or black and white, or } \\
\text { brindle, Horns are short and thick and lateral rather than upright (as in the } \\
\text { Malawi Zebu), hump and dewlap are well developed, Heavy males weigh up } \\
\text { to } 730 \mathrm{~kg} \text {. }\end{array}$ & - & [163] \\
\hline Landim & Mozambique & $\begin{array}{l}\text { Coat colour is black, white, dark brown, brown and white. Have long and } \\
\text { short horn. Some have long and short outward or inward curling horns. }\end{array}$ & - & [163] \\
\hline $\begin{array}{l}\text { Barotse, } \\
\text { Tswana, } \\
\text { Malawi Zebu, } \\
\text { Ankole }\end{array}$ & Botswana & $\begin{array}{l}\text { The usual coat colours are brown, dark red, fawn or black, sometimes mixed } \\
\text { with white although pure white colour has never occurred. They have lyre-shaped } \\
\text { horns. Wither heights of mature male and female animals are } 120 \text { to } 137 \text { and } \\
114 \text { to } 129 \mathrm{~cm} \text {, respectively. Bulls weigh up to } 700 \mathrm{~kg} \text { and cows } 485 \mathrm{~kg} \text {. }\end{array}$ & - & [17] \\
\hline
\end{tabular}

Mashona cattle were more resistant to ticks and had high calving and weaning rate under marginal environmental conditions characterising most smallholder areas when compared to some exotic breeds. The resistance to ticks in sanga breed has been attributed to coat characteristics such as colour, hair length and density [48], grooming behaviour and delayed cutaneous hypersensitivity reaction to tick infestation [65]. An understanding of the mechanisms behind genetic resistance to ticks and TBD in livestock species could improve breeding programmes to develop animals that are more resistant and productive [62]. Genetic variation in resistance of livestock should be quantified within and across breeds so that appropriate strategies are adopted in breeding programmes. The host and tick genomics and their proteomics, such as gene expression profiles, are likely to facilitate studies addressing the sequencing, annotation, and functional analysis of their entire genomes [62]. This could provide valuable information for improving tick control.

\section{Resistance to tick borne diseases}

Besides causing blood loss and decreased milk or meat production, ticks transmit a number of diseases, including babesiosis, anaplasmosis, and cowdriosis. The Nguni cattle of Southern Africa have been reported to be resistant to tickborne diseases [60]. Marufu et al [60] showed that, Nguni cattle had lower seroprevalence for Anaplasma marginale and Babesia bigemina in the cool-dry and hot-wet seasons. The seroprevalence of TBD

Table 3. Cattle breeds and their level of resistance to specific tick species

\begin{tabular}{lcl}
\hline Cattle breeds & Level of resistance & \multicolumn{1}{c}{ Tick species } \\
\hline Nguni compared to Hereford \& Brahman & High & Rhipicephalus decoloratus \\
Zimbabiansanga compared to Nguni and Brahman & High & Amblyomma variegatum, Rhipicephalus decoloratus \\
Boran compared to Tulis & High & Rhipicephalus microplus \\
Nguni compared to Bonsmara and Angus steers & High & Rhipicephalus appendiculatus \\
Nguni breed compared to indigenous-exotic crosses & High & Rhipicephalus appendiculatus, Hyalomma species \\
(non-descript cattle) & & Rhipicephalus microplus \\
Nguni cattle compared to Bonsmara & High & [166] \\
\hline
\end{tabular}


was lower in the Nguni breed [60]. Indigenous cattle have been known to have natural resistance to TBD [67]. As a result, they perform better under harsh environmental conditions and in as much as ticks may affect them the damage will be minimal as compared to European breeds.

\section{Resistance to nematodes}

Parasite infections are one of the greatest causes of diseases and loss of productivity in livestock with most grazing livestock being at risk from infection by gastrointestinal (GI) nematode parasites [68]. Besides TBD, internal parasites, GI nematodes in particular, are among the important factors limiting cattle productivity in Southern Africa. Grazing ruminants are always exposed to GI, which reduce feed intake, feed conversion efficiency, growth performance [69,70,71], draught power performance and cow fertility [72], can result in loss of blood and even death [73]. These parasites are a significant impediment to the efficient raising of cattle on rangelands [74]. Only the presence of worms and deaths in cattle are noticed by resourcepoor farmers and viewed as the most important economic losses [73]. The greatest economic losses associated with nematode parasitic infections however, are subclinical [69] and these go unnoticed in cattle on rangelands. For the objective assessment of economic losses caused by GI nematodes in cattle on communal rangelands, there is a need to identify common nematodes and determine their load and prevalence. Information on nematodes loads and prevalence conducted under both uncontrolled and controlled on-station conditions is limited. Ndlovu et al [52] compared three breeds across seasons on sweet rangeland in South Africa and found that indigenous Nguni cattle had the lowest faecal egg counts compared to Bonsmara and Angus. [75] and [76] revealed that, Nguni versus non-descript crossbred cattle had the lowest egg loads and worm burdens. Further research to determine the resilience of the Nguni breed to internal parasites, especially GI could be important.

\section{Resistance to trypanosomosis}

Tsetse-transmitted trypanosomosis continues to be a serious and costly disease to cattle, despite multifaceted attempts to control it [77]. Although trypanocidal drugs can be useful, parasite resistance to these drugs increases yearly. Fortunately, locally adapted beef cattle breeds such as Nguni, Tuli, Tswana, and Mashona found in areas of high tsetsefly challenge show consistent tolerance to these infections [78]. Various studies have been undertaken since 2007 to elucidate the biological basis for trypanotolerance $[79,80,78]$. Two physiological mechanisms seem to be involved: i) increased control of parasitaemia; and ii) greater ability to limit anaemia [77]. Overall, mechanisms of disease and parasite resistance, resilience or tolerance of indigenous beef cattle and the probable development of immunity merit investigation [81].

\section{Heat tolerance}

Exceptional challenges faced by livestock in arid and semi-arid environments are numerous, but heat stress is one of the major challenges that animals have to deal with for a longer period of the year [82]. Heat stress in beef cattle on veld/savannah is expected to increase as a result of changing weather patterns on a global and regional scale $[83,84]$. High ambient temperatures outside the thermo-neutral zone cause significant changes in physiological processes including feed intake, due mostly to the direct effects of thermal stress. Nardone et al [85] revealed that, hot environment impairs production (growth, meat, and milk yield and quality) and reproductive performance, metabolic and health status, and immune response. Gregory et al [86] revealed that, heat could affect meat quality in two ways. First, there are direct effects on organ and muscle metabolism during heat exposure which can persist after slaughter. Second, changes in cattle management practices in response to temperature changes could indirectly lead to changes in meat quality. For example, changing to heat-tolerant Bos indicus cattle sire lines could lead to tougher beef. Owing to their adaptation to local environments, it is important to find ways of conserving indigenous cattle breeds in Southern Africa.

\section{METHODS OF CONSERVING INDIGENOUS BEEF CATTLE BREEDS}

There are two major conservation methods; in situ and ex situ conservation, which are interlinked [15]. The ex situ method involves conservation of animals in a situation removed from their habitat. It is the storage of genetic resources not yet required by the farmer and it includes cryogenic preservation. The in situ method is the conservation of live animals within their production system, in the area where the breed developed its characteristics $[87,88]$. It can also be referred to as on-farm conservation. Such conservation consists of entire agro-ecosystems including immediately useful species of crops, forages, agroforestry species, and other animal species that form part of the system [89]. Under the in situ conditions, breeds continue to develop and adapt to changing environmental pressures, enabling research to determine their genetic uniqueness.

According to the World Watch List for Domestic Animal Diversity prepared by the [90], the requirements for effective management for conservation needs at the country level for each species include identifying and listing the breeds. Therefore, this conservation provides opportunities for utilisation, breed evolution and development, maintenance of production and agro-ecosystems and ecological development. There is consensus that in situ conservation is the method of choice for the smallholder farmers [91]. The Convention on Biological Diversity, FAO and various workers [92] also emphasized the importance of strong in situ programmes supported by ex situ complementary measures. The costs can be borne by the farmers themselves, 
governments or commercial entities that may develop niche market products from the genotypes [93]. In situ conservation has the main disadvantage that the forces that currently threaten genetic resources remain [92]. Given that most local breeds have small effective populations the risks of inbreeding and genetic drift are always high. In addition, small populations tend to be more vulnerable to unforeseen disasters [8]. One of the biggest problems inq Southern Africa is lack of resources to develop in situ conservation programmes.

In Southern Africa, most countries for example South Africa, Zimbabwe, Botswana and Malawi are well-endowed with structural capacity to effectively run in situ and ex situ breed conservation strategies. An establishment of a unity of purpose is vital for the success of the programme in these countries [94]. These countries have many institutions both government research centres, parastatals, universities, colleges and breed societies which can spearhead the conservation of animal genetic resources for smallholder beef cattle farmers. These institutions could also be mandated to take charge of the indigenous cattle breeds by employing in situ conservation and cryo-preservation with utilisation. A minimum effective population size of 250 animals per breed per institution would be ideal to minimise inbreeding and maximise the contribution of each individual to the next generation $[92,95]$. The technical knowhow, infrastructural development and land sizes can accommodate at least one breed per institution. Funding through subsidies based on the difference between the potential production of the conserved strain and that of the alternative replacement breed or its crosses could be important. Parastatal institutions in Southern African countries may offer crucial support for the smallholder areas to implement in situ conservation of smallholder beef cattle genetic resources. Selection on characteristics traditionally valued (adaptability, low plane of nutrition, disease resistance, cow productivity, and growth performance) could be done with the help from these institutions organised at local level. Concerted efforts of private corporate (Breed Societies, farmer unions, non-governmental organisations) and government parastatals would provide long-term funding, personnel, capital to mobilise stock and implement a well-planned breeding programme. Farmer-based projects can be funded nationally and be coordinated through central programmes. The projects can be effective and conserved breeds continue to adapt and evolve within sustainable changes in local agricultural practice, climatic and environmental conditions of Southern African countries. It is therefore important for different stakeholders to participate in the conservation of beef cattle breeds in Southern African smallholder farming communities.

\section{STAKEHOLDERS IN CONSERVATION OF BEEF CATTLE BREEDS}

Farmers
Farmers are the custodians of farm Animal Genetic Resources (AnGRs) [15]. They come in different hues from commercial to subsistence smallholder farmers. Each has an interest in the current and future AnGR and is usually called upon for in situ conservation efforts. For successful conservation programmes, farmers need information on the value of the smallholder beef cattle genetic resources, training on beef cattle production, access to markets and other services, recognition of their rights, economic and legal incentives and legislative support for benefits sharing $[64,96,97]$. In addition, current carcass classification systems tend to disfavour the smallholder beef cattle as compared to the exotic breeds kept in commercial farms [98].

A study by [94] showed that, almost all indigenous cattle in the smallholder sector are not performance recorded because of the numerous functions they perform. Although this national pool of indigenous cattle breeds has been diluted by introduction of exotic genotypes, there remain some areas where relatively pure stocks can still be found $[99,100]$.

\section{National government}

There are several stakeholders involved in or who should benefit from conserving AnGR [101]. One of the key stakeholders is the national government as the custodian of legislation, national policy and also as an active participant of conservation; and as a signatory to most conventions that aim to conserve AnGR (e.g. Convention on Biological Diversity). Issues of sovereignty, rights and fair trade can only be addressed at the government level [89]. There are examples worldwide where governments have taken a lead role in conserving AnGR [102,103,15], and Southern African governments can do the same. It seems only the South African government, is the only country in Southern Africa with a conservation programme in place for local pigs. This initiative can be successfully harnessed to conserve indigenous beef cattle breeds from a country grouping perspective by incorporating other Southern African countries.

In 1998 the Department of Rural Development and Agrarian Reform (DRDAR) in South Africa came up with a Bull Scheme in the smallholder and small-scale commercial sector of the rural communities $[104,105]$. The project distributed high performing Nguni bulls to control inbreeding in the smallholder areas. This facilitated effective community management institutions to develop cattle production and marketing opportunities for Nguni cattle in rural areas [105]. This programme initially introduced 35 Nguni bulls into five communities in the Northern Province and six communities in the Eastern Cape [106,105]. These communities had organized farmer groups that were willing to participate in a development scheme and to contribute a minimal amount towards the maintenance of the bulls. At the end of three years, the community returns the bull, which will then be placed in another community. Farmers were not encouraged to remove or castrate existing exotic breeds in their area but merely to upgrade the community animals to Nguni breed [107]. 
By the year 2008, about 150 registered Nguni bulls were distributed across the rural communities of the Eastern Cape Province. The Bull Scheme was considered slow in effecting change in the communities. This was because of the presence of other bulls of several breeds/genotypes. There was no recording of animal performance and record keeping. This also meant that conservation efforts of the Nguni breed did not have much impact. Despite these weaknesses, the Bull Scheme is still operational [108] and is important for the conservation of smallholder beef cattle genetic resources. Therefore for effective conservation, there is need for accurate records when measuring animal performance for example bulls through performance testing. The government is also recommended to build infrastructure for smallholder beef cattle.

\section{Research institutes and universities}

Technological adjustments and the increasing consideration of target group involvement in livestock breeding programmes may offer better possibilities for raising production by breeding in low-input and medium-input livestock breeds. In that regard, research institutes should contribute to the research, documentation, inventory and characterisation of AnGR [15]. For example, the University of Fort Hare (UFH) Honeydale farm maintains a large population of indigenous Nguni cattle which has been the subject of various studies (Table 4). Research institutes in Zimbabwe rear some indigenous beef cattle for example the Mashona cattle at Henderson and Makoholi and Nguni cattle at Matopos Research stations. The Mara research station in South Africa keeps Bonsmara herd of cattle whilst the Chitedze research in Malawi keeps the Malawi Zebu. However, these efforts are not well coordinated and should be more focused for them to have an impact on the conservation of local beef cattle breeds. Ex situ conservation of beef cattle genetic resources can be done on farms of research institutes and universities with the assistance of the government. The Nguni cattle of South Africa are a model example of the ex situ in vivo conservation of an indigenous breed: they were conserved on government farms as well as university farms (e.g University of Fort Hare) and, once their numbers had been increased by breeding, they were made available for commercial production.

\section{Initiatives by the University of Fort Hare and other development agencies}

The UFH was instrumental in initiating the community-based

Table 4. Summary of some key studies on local beef cattle breeds in Southern Africa

\begin{tabular}{|c|c|c|c|}
\hline Focus area & Summary of findings & Comments & References \\
\hline Meat quality & $\begin{array}{l}\text { Growth and carcass characteristics and meat quality } \\
\text { traits of Nguni cattle fed natural pasture-based feed } \\
\text { resources }\end{array}$ & Nguni cattle had the potential of producing meat & {$[49,16]$} \\
\hline Ticks and tick borne disease & $\begin{array}{l}\text { Prevalence of ticks and tick-borne diseases in cattle on } \\
\text { smallholder rangelands in the highland areas of the } \\
\text { Eastern Cape Province, South Africa }\end{array}$ & $\begin{array}{l}\text { Nguni cattle were recommended for use in the } \\
\text { integrated control of ticks and TBD in the smallholder } \\
\text { areas of South Africa as they were better able to } \\
\text { cope with tick and TBD infestations than non-descript } \\
\text { breeds. }\end{array}$ & $\begin{array}{c}{[48,61,65]} \\
{[62,47]}\end{array}$ \\
\hline Nematodes & $\begin{array}{l}\text { Supplements containing Acacia karoo foliage reduce } \\
\text { nematode burdens in Nguni and crossbred cattle. } \\
\text { Animal Production Science. Nematode worm burdens } \\
\text { in Nguni cattle on communal rangelands in a semi-arid } \\
\text { area of South Africa. }\end{array}$ & $\begin{array}{l}\text { Nguni cattle supplemented with Acacia Karoo leaf } \\
\text { meal had the lowest egg loads and worm burdens. It } \\
\text { was concluded that supplementing cattle with Acacia } \\
\text { Karoo could reduce nematode burdens. }\end{array}$ & {$[75,52,48]$} \\
\hline Beef production opportunities & $\begin{array}{l}\text { Opportunities for improving Nguni cattle production in } \\
\text { the smallholder farming systems of South Africa }\end{array}$ & $\begin{array}{l}\text { Farmer's socio-economic and pedo-climatic situations } \\
\text { should be considered when planning strategies for } \\
\text { cattle development. }\end{array}$ & {$[16]$} \\
\hline breeding & $\begin{array}{l}\text { Reproductive efficiency and herd demography of Nguni } \\
\text { cattle in village-owned and group-owned enterprises } \\
\text { under low-input smallholder production systems }\end{array}$ & $\begin{array}{l}\text { The bulling rate was higher in village-owned enter- } \\
\text { prises, while the proportion of breeding females was } \\
\text { higher in group-owned enterprises. }\end{array}$ & [98] \\
\hline Beef cattle adaptation & $\begin{array}{l}\text { Farmers' Perceptions and Knowledge of Cattle Adapta- } \\
\text { tion to Heat Stress and Tick Resistance in the Eastern } \\
\text { Cape, South Africa }\end{array}$ & $\begin{array}{l}\text { Results showed that farmers in the two municipalities } \\
\text { had knowledge of cattle adaptation to heat stress and } \\
\text { tick resistance. }\end{array}$ & [122] \\
\hline Seasonal variations & $\begin{array}{l}\text { Seasonal variation in coat characteristics, tick loads, } \\
\text { cortisol levels, some physiological parameters and } \\
\text { temperature humidity index on Nguni cows raised in } \\
\text { low- and high-input farms }\end{array}$ & $\begin{array}{l}\text { It was concluded that the location, coat colour and } \\
\text { season had effects on hair length, cortisol levels, THI, } \\
\text { HP and tick loads on different body parts and heat } \\
\text { stress in Nguni cows. }\end{array}$ & {$[167] ;[61,65] ;[123,167]$} \\
\hline Animal physiology & $\begin{array}{l}\text { Comparative changes in monthly blood urea nitrogen, } \\
\text { total protein concentrations, and body condition scores } \\
\text { of Nguni cows and heifers raised on sweet veld }\end{array}$ & $\begin{array}{l}\text { The Nguni cows and heifers had variations in the } \\
\text { levels of BUN and TP concentrations in the various } \\
\text { months while maintaining a steady body condition } \\
\text { score throughout the trial. }\end{array}$ & {$[123] ;[167,47,16]$} \\
\hline
\end{tabular}


conservation of Nguni cattle in South Africa $[105,21,95]$ as a follow-up of the Bull Scheme. By engaging the Development Bank of Southern Africa, Industrial Development Cooperation, ECDRDAR, and private donor, Adam Fleming, the Nguni Cattle Programme became widespread in the Eastern Cape Province $[109,105,95,110,98]$. The programme became visible in the EC province uplifting the livelihoods of cattle farmers in smallholder and small-scale commercial areas and maintenance of genetic material of the Nguni breed $[95,98]$. Interested communities were offered two registered bulls and 10 in-calf heifers to allow them to build up a smallholder open-nucleus herd. All the existing bulls in the community were replaced by registered Nguni bulls. After five years, the community enterprise would give back to the project two bulls and 10 heifers, which are then passed on to another community $[105,19]$. The 'pay it forward' system was used where each community pays dividends of its original gift to another. Some of the conditions of the project were; communities should have fenced grazing areas and practicing rotational resting at specified stocking rates [105].

The beneficiaries of the Nguni Cattle Programme were either a rural farming community/village or emerging/small-scale farmers in LRAD farms [98]. The programme aimed at empowering rural farmers with livestock farming skills and developing their entrepreneurship abilities. This was after the realisation that cattle ownership is fundamental to social status and selfesteem of the rural farmers [110]. The long-term goal of the programme was to develop a niche market for Nguni beef and skins and to position the smallholder and small-scale farmers for the global beef market through organic production and product processing [19]. The Nguni Cattle Programme has so far benefited 72 communities in the Eastern Cape Province out of the target of 100 as at July $2012[95,98]$. The participatory approach of the programme provides a sustainable mechanism of establishing dispersed nucleus of Nguni herds in the rural areas. The Nguni Cattle Programme has a development committee, made up of interested stakeholders, in charge of the development of infrastructure, training of farmers, and the redistribution of animals. The implementation of the model is conducted in collaboration with the ECDRDAR $[105,111]$. The determination of breeding objectives with farmer participation for this in situ conservation is considered important for the sustainability of the programme. The active participation of the Industrial Development Cooperation IDC saw the involvement of five other provinces after 2006 targeting emerging black farmers and rural farming communities using the same criteria. The provinces include Limpopo, North West, Northern Cape, Free State, and Mpumalanga. The size of the nucleus herd was increased to one bull to 25 to 30 in-calf heifers [112]. Official data on the success of the initiatives is scanty with reports of seventeen beneficiaries in Mpumalanga Province, six in Northern Province and four in North West. In the KwaZulu Natal (KZN) Province, conservation activities are promoted by the KZN
Nguni cattle club which is a non-profit organization. The KZN Nguni cattle club strives to conserve and enhance the unique characteristics of the Nguni cattle breed, and promote the proliferation of the Nguni population in the province [113]. Therefore, the Nguni cattle improvement programmes are recommended to supply a complete package of back up services such as genetic resources, performance recording schemes, genetic evaluation, rangeland management aids and appropriate infrastructural support to the benefiting communities. There is need for effective and continuous monitoring and evaluation of these projects, especially in the implementation phases to detect and rectify unfavourable developments on time.

\section{Breeding companies and societies}

Breeding companies tend to conserve genetic diversity within and between their inbred lines and they also tend to have patent protection for their genetic resources [102]. Breeding societies like the Nguni, Tuli, and Mashona cattle breeders societies are also involved in breeding and conservation of beef cattle genetic resources. However, they are also interested in the future value of AnGR diversity because they are the ones that are most affected financially by any deleterious change in production environment. The consumer is the main driver of changes in the market and is also the source of money for conservation efforts [114,15]. The value of the consumer might not be very significant in relation to conservation of smallholder beef cattle genetic resources as 'most of the benefits produced by local livestock in marginal production systems are captured by producers, rather than consumers' [114]. However, a close integration between the consumer and the producer in the value chain has produced benefits elsewhere and would be of use in Southern Africa). Breeding programmes are, therefore, suggested for Southern Africa within the concept of regional genetic improvement programmes controlled by breed societies, breeding companies, government and national agricultural research systems.

\section{POTENTIAL COST IMPLICATIONS OF CONSERVATION}

Every sound conservation effort bears a cost which differs with perspective on the particular population or breed, countries, regions and production environments [114,91]. Although the conservation potential is considered as a good indicator for conservation decisions, it does not give information on how to allocate the conservation budget to maximize the conserved diversity [91]. It is necessary to assign appropriate shares of the conservation budget to the different breeds once the decision is made as to which population or breeds should be sampled. Several methods of estimating the likely cost of conservation efforts has been described elsewhere $[115,92,116]$. Firstly, the costs and effects for the different conservation schemes in terms of reduced extinction probability need to be established and 
known. The costs can typically be subdivided into variable costs, which depend on the number of beef cattle cryo-conserved sample and the fixed costs, which are necessary to establish the conservation scheme inter alia.

\section{THREATS AND OPPORTUNITIES TO CONSERVATION OF INDIGENOUS CATTLE BREEDS}

\section{Low cattle productivity}

Cattle feed shortages, high incidences of diseases and parasitism, poor breeding practices and poor marketing management are the major threats to beef cattle production $[117,16,118]$. These threats limit smallholder beef production and hence the need to characterize and conserve indigenous beef cattle genetic resources for sustainability of smallholder beef farmers in Southern Africa.

\section{Quality and availability of animal feed}

Extensive grazing is the common practice by the resource-poor farmers where animals entirely rely on communal natural pasture $[119,98,118]$. Seasonal deficiency in feed quality and quantity particularly during the second half of the dry season is the major constraint to smallholder livestock production $[16,120]$. Poor management of natural pastures, inappropriate grazing management, and natural pasture fires also limit the availability of fodder in the smallholder areas [121]. Natural pasture quality and quantity is highly variable in the tropics with crude protein dropping below $5 \%$ in the dry season $[122,123]$. In the sour natural pastures (sourveld), the highest crude protein values are recorded during the wet season. The reduction in protein content of grasses and the increase in lignin content during winter reduce the overall digestibility of the grasses [124]. Information on the effect of seasonal changes on feed dynamics and management in smallholder areas is scarce, making it difficult to assess the efficiency of utilisation of smallholder natural pastures by beef cattle [106]. In a study by $[125,126]$, it was revealed that crossbreds had higher body weights than Nguni cattle. Sweet rangeland had lower cattle weights than the sour rangeland. Body weights for both breeds were higher on the sweet rangeland in the hot-wet and post-rainy seasons compared to other seasons. The observed breed differences in ALP values in the hot-dry and hot-wet seasons reflect differences in growth, body size and weight for the cattle in this study. Small framed animals, have low feed intake and, consequently, lower skeletal growth [127] than local crossbreds. Therefore the opportunities for using indigenous beef cattle breeds are that they are drought resistant and they survive in the natural pastures sometimes under limited forage and hence they need to be conserved.

\section{Prevalence of diseases and parasites}

In Southern Africa, diseases are a major constraint to livestock production $[48,61,62]$. Animal health issues are barriers to trade in livestock and their products, whilst specific diseases decrease production and increase morbidity and mortality $[16,48]$. These diseases include anthrax, foot and mouth disease, black-leg and contagious abortion. The outbreaks of such diseases in Southern Africa can be a threat to the smallholder cattle producers who do not have medicine and proper disease control infrastructure $[61,62]$. Furthermore, movement of cattle and their by-products are difficult to monitor in the smallholder areas. The effects of endo- and ecto-parasites are mainly high mortalities, dry season weight loss which reduce fertility through nutrition induced stress [48]. This has negative financial implications in controlling the effects of diseases [128] and productivity implications as $70 \%$ of calves are born during the dry season [129]. Studies by [130] and [120] cited smallholder herd mortality rate as high as $18 \%$, with disease accounting for $60 \%$ of herd mortality for smallholder cattle in Masvingo district [131]. The most common diseases reported by farmers are cowdriosis and babesiosis [120, 131]. The situation is worsened by the unavailability and high cost of drugs [132] and inadequate veterinary officials [16]. A survey by [133] has shown that most of the farmers raising cattle are rarely visited by veterinary officials serve for contact with the dip attendants during dipping days.

The farmers rarely use drugs to treat their animals as they have limited access to veterinary care in terms of support services, information about the prevention and treatment of livestock diseases, and preventive and therapeutic veterinary medicines [60]. The concerned farmers rely on the use of traditional medicines to combat the constraint of nematodes, ticks and tick borne diseases $[117,133,95]$. The epidemiology, burdens and susceptibility to parasites and diseases in different classes and strains of livestock require research $[134,118]$. Parasites with huge impacts on growth and mortality, such as tapeworm, should be prioritised in the research efforts [135]. Affordable ways of controlling parasites, such as the use of ethno-veterinary medicines should also be evaluated to complement the conventional control methods [136] as they can provide low-cost health care for simple animal health issues [137]. It is therefore important to conserve and use local adapted beef cattle breeds which are resistant to local diseases and parasites.

\section{Poor marketing management}

Livestock marketing, in most smallholder areas, is poor and characterised by absent or ill-functioning markets [138]. A baseline study by the International Crop Research Institute in Semi Arid Tropics (ICRISAT) revealed lack of organised marketing of beef cattle in Zimbabwe smallholder areas [130]. Smallholder farmers resort to the informal way of marketing their cattle where pricing is based on an arbitrary scale, with reference to visual assessment of the animal. Middlemen are the main buyers and purchase live animals from farmers for resale at cattle auction points and to abattoirs in towns often benefiting more than the 
farmers themselves [131]. Apart from selling to local butcheries, farmers do not have ready markets where they can take their animals to if they need to sell their animals therefore usually end up under-pricing their animals in cases of emergencies [130]. Generally, smallholder cattle production in South Africa has been associated with a low off-take rate of $2 \%$ to $5 \%$ and hence there is need for marketing of the indigenous beef cattle so that more priority is given on their conservation which will improve on their pricing as well $[139,140]$.

\section{Poor breeding practices}

Lack of controlled breeding in smallholder areas result in inbreeding, which then cause poor growth rates in cattle [133,141]. Recent studies in the rural communities of South Africa practicing low-input animal agriculture have highlighted the concern of cattle breeding practices [16,104], a high bulling rate, and a high number of young bulls, heifers and young cows [142,98]. Absence of animal selection was observed in communal and small-scale Nguni cattle enterprises practising community-based in-situ conservation [106,104]. The Nguni, an indigenous cattle breed in South Africa, found in rural areas have not undergone the intensive selection programs that are used for the exotic and commercially-oriented breeds [143]. This can be because of the uneasiness and rigorous nature of standard performance data collection to the majority of the less educated communal dwellers [144]. Cattle records for traits of economic importance are needed for accurate performance evaluation in terms of performance trends, selection criteria and mating system designs. It is therefore prudent to base animal selection on the high-value traits that a communal farmer understands, easily measure, and derive direct economic value. There are no structured breeding systems and appropriate infrastructure such as paddocks, therefore, cows and bulls of unknown genetic merit and bloodlines run together all year round [104]. In developing countries and low-input production systems such breeding schemes and structures are uncommon and livestock farmers have usually limited access to improved breeding stock or artificial insemination services and rely mainly on their own traditional breeding practices [141]. Often improved genetic material with the desired characteristics for the particular production environment is not available [141].

Animal performance recording systems have been known for long to affect genetic improvement programs with negative results in the communal areas of most developing countries [145]. The absence of performance records, particularly of the indigenous breeds, can lead to undefined breeding seasons and random mating [104]. A considerable number of livestock breeding programs have been reported to have failed because of poor performance data recording and trait identification [146]. The consequences of uncontrolled mating are well documented and include, among others; production of un-uniform animals, presence of undesirable and genetic defects, and inbreeding depression $[121,147]$. Furthermore, the potential to alleviate poverty and improve food security through livestock development interventions in the smallholder sectors of most developing countries was hampered by lack of participation in the planning and designing of breeding programs by the community [ $[145$, $148,146]$.

\section{Cattle ownership and gender roles}

These socio-economic characteristics of the farming environment such as cattle ownership necessitate participatory determination of breeding objectives for in situ conservation $[110,16]$. Some level of input from the farmers could be important in sustaining the conservation initiatives in terms of objective assessment of animals, mating strategy and performance recording. Cattle ownership is strongly skewed, with a small number of people owning large herds and the majority owning few animals or none at all and stock numbers tend to be less evenly distributed in smallholder areas than in small-scale commercial areas [16, 106]. The smallholder farmers tend to have multiple owners of cattle within a herd and to some extent one animal have two or more owners $[105,106]$. Cattle ownership is mostly male-dominated with duties carried out by children and older age-groups that are mainly found in the rural areas $[110,16]$. Cattle ownership has been thought as a fundamental basis of social status and self-esteem to the rural farmer [110]. To identify constraints and opportunities for technological interventions into smallholder beef production, gender analysis should be carried out. This will assist in preventing frequent misdirecting of technologies and services to the wrong gender group. According to [149], gender analysis is a tool for understanding men and women's roles and the responsibilities in various activities, their use of resources, access and control to resources and benefits, participation in decision-making and contribution to household income and food security $[149,16,106]$. The involvement in different types of agricultural work for men and women in most African communities depend mostly on social, cultural, local customs and religious influence [149150].

\section{Infrastructure and cattle handling facilities}

Most of the infrastructure and cattle handling facilities and dip tanks in the smallholder areas in Southern Africa were built using funds from local or national governments and development agencies [150]. Cattle facilities make it easy to carry out the basic animal husbandry activities such as animal identification, castration, pregnancy diagnosis, animal treatment, vaccinations and live-weight measurements. For example, about 75\% of rural livestock owners in the Eastern Cape province of South Africa use cattle handling facilities when treating their sick animals with herbal plants $[168,95,98$,] which need close contact with the animal. This investment is thought to enhance the husbandry activities thereby improving efficiency of the conservation initiatives. 


\section{Extension and services}

The role of extension workers is to get information from the researcher and transmit it to the rural farmers [151]. In Zimbabwe for example, the extension farmer ratio is 1:250 in some smallholder farming areas. To fulfil this role effectively extension workers should keep abreast with new technological developments through strong linkages with researchers. Extension officers play a role in using the participatory appraisal techniques to identify cattle marketing problems and solutions [152]. Furthermore, this improves service delivery, thereby accelerating agricultural development $[149,16,106]$. The involvement of community members using a bottom-up approach can instil the sense of ownership and responsibility and enable them to maintain their infrastructure [151,95]. Extension officers can cooperate with smallholder people and aid them in managing the conservation initiatives and improving the productivity of animals. The conservation and monitoring process of the programme initiatives are therefore best achieved with competent extension personnel.

\section{FURTHER RESEARCH}

Overall, information about phenotypic and genotypic description, distribution, total and individual numbers of indigenous cattle breed in Southern Africa and their contribution to household food security and income, and adaptation to the changing local environment is lacking. Research effort should, therefore, be made to further characterize indigenous cattle breeds, generate accurate statistics on breed numbers and their contribution to household economy and food security. It should also focus on the adaptation of the indigenous cattle to the effects of climate change. It is also important to develop sustainable research programmes and projects that appropriately address the challenges that Southern African smallholder beef cattle producers face. Inadequate description, classification and evaluation of cattle have resulted in a poor understanding of the potential indigenous cattle breeds [4]. Breed differences can be established through molecular taxonomic characterisation, which can, in turn, serve as a guide on decisions relating to conservation $[98,118]$ and improvement of these breeds [82]. Attributes of each breed will have to be identified and evaluated, to develop appropriate and sustainable breeding programmes. Microsatellites and single nucleotide polymorphisms (SNP) can be used with ease in the studying of DNA sequence and variation $[121,8,62]$ and result in enormous selection response. It could be important to conduct research in the smallholder areas, using modern technologies such as microsatellites to characterise cattle based on genetic diversity rather than region of origin since these animals may be genetically similar $[8,62]$. The rapid advances in genome sequencing and high-through put DNA techniques have led to new and more precise measures of genetic diversity and coancestry and inbreeding coefficients [62]. These new measures can be used in the genetic management of populations for increasing its effectiveness [153]. In South Africa, microsatellites have been used to evaluate the genetic diversity among indigenous cattle and identify different cattle strains [154,62]. Recently technological advances in molecular genetics have greatly improved our ability to use information on DNA polymorphisms to select livestock [154]. Genome-sequencing efforts have resulted in the availability of a reference genome sequence for most livestock species including cattle. This has also resulted in the discovery of many thousands, and even millions, of SNPs, which are single-base pair variations of individuals from the reference genome. These SNPs can be genotyped in a cost-effective way by modern SNP-chip genotyping technologies [154]. For most of the major livestock species including cattle, low-cost SNP arrays ("chips") with approximately 50,000 genome-wide SNPs are available. For cattle, a 700,000-SNP chip can be used as well.

To effectively design sustainable genetic improvement programmes, correct matching of genotypes with the prevailing and projected socio-economic and cultural environments should be considered [155], breeding objectives should be clearly defined. Adaptive traits, such as resistance to diseases and parasites and their adaptation to extreme weather conditions [4] and for traits of economic importance such as calving interval, age at puberty, age at first calving [154] should be emphasized to improve smallholder cattle production. Programmes that encourage farmers to keep records should be developed since the records form the basis for genetic improvement. Regarding within-breed selection, realistic performance and pedigree recording, with active farmer participation should be adopted so that breeders can use the records to help select superior animals. Indigenous breeds should be prioritised in selection of individual cattle for smallholder herd improvement. For example, [155] reported $74 \%$ calving rate for Mashona cows almost 20\% higher than that of Sussex (56\%), indicating the importance of selecting cattle before using them as breeding animals at smallholder level.

\section{CONCLUSION}

Although smallholder beef cattle in Southern Africa are hardy, their productivity is hindered by several constraints that include high prevalence of diseases and parasites, limited feed availability and poor marketing. It is important to develop concerted, coordinated and comprehensive farmer training, research and development programmes to address these constraints for smallholder beef cattle producers. Conservation of Southern African beef cattle genetic resources could be imperative as these have been shown to be a useful integral part of agro ecosystems in some smallholder areas. The reasons for conserving smallholder beef cattle vary from current utility to the ability to meet future challenges in a dynamic environment. The options available include in situ, ex situ conservation techniques and their combination. There is a big policy gap in Southern Africa with regard 
to conservation of AnGR in general and it is imperative that policy makers be made aware of the value of AnGR. The costs of conservation can be met by increasing the market value of neglected breeds so that they eventually become self-sustaining. This requires the identification of the beef breeds, their characterization and development of marketable products from these breeds. The nations in Southern Africa have the potential to apply breed conservation strategies through securing longterm funding, revamping institutional activities, training technical personnel and co-ordination of management efforts. By so doing, this will promote conservation of smallholder beef cattle and enhance sustainable development to smallholder beef cattle farmers.

\section{CONFLICT OF INTEREST}

We certify that there is no conflict of interest with any financial organization regarding the material discussed in the manuscript.

\section{ACKNOWLEDGMENTS}

This work was supported by a grant from the National Research Foundation (NRF), Republic of South Africa. We thank Lizwell Mapfumo, Denice Chikwanda and Allen Chikwanda for constructive suggestions on the study and for helpful comments on the manuscript.

\section{REFERENCES}

1. Thornton PK. Livestock production: recent trends, future prospects. Phil Trans R Soc B Biol Sci 2010;365:2853-67.

2. Hoffmann I. Climate change and the characterization, breeding and conservation of animal genetic resources. Anim Genet 2010; 41:32-46

3. Kohler-Rollerfson I. Farm animal genetic resources: Safeguarding national assets for food security and trade. Summary Publication about four Workshops on Animal Genetic Resources held in the SADC Region. FAO/GTZ/CTA; 2004.

4. Khombe CT 2002. Genetic improvement of indigenous cattle breeds in Zimbabwe: A case study of the Mashona group breeding scheme. http://agtr.ilri.cgiar.org/index.php?option=comcontent\&task=vi ew\&id=82\&Itemid=99

5. Scholtz MM, Bester J, Mamabolo JM, Ramsay KA. Results of the national cattle survey undertaken in South Africa, with emphasis on beef. Appl Anim Husb Rural Dev 2008;1:1-9.

6. MacNeil MD, Matjuda LE. Breeding objectives for Angus and Charolais specialized sire lines for use in the emerging sector of South African beef production. S Afr J Anim Sci 2007;37:1-10.

7. Intenrnational Livestock Research Institute. Climate, livestock and poverty. Challenges at the interface. Corpkorate report. 2008-2009; Intenrnational Livestock Research Institute, 2008.

8. FAO. In: Rischkowsky B, Pilling D, editors. The state of the world's animal genetic resources for food and agriculture. Rome, Italy: FAO; 2007. p. 511.

9. Bayer W, Alcock R, Gilles P. Going backwards? Moving forward? - Nguni cattle in communal KwaZulu-Natal. "Rural Poverty Reduction through Research for Development”. Deutscher Tropentag, Berlin; 2004.

10. Rege JEO. The state of African cattle genetic resources I. Classification framework and identification of threatened and extinct breeds. Anim Genet Resour 1999;25:1-25.

11. Rege JEO, Ayalew W, Getahun E, et al. Domestic Animal Genetic Resources Information System (DAGRIS). Addis Ababa, Ethiopia: International Livestock Research Institute; 2007.

12. Rewe TO, Herold P, Kahi AK, Zárate AV. Breeding indigenous cattle genetic resources for beef production in Sub-Saharan Africa. Outlook Agric 2009;38:317-26.

13. Hanotte O, Tawah CL, Bradley DG, et al. Geographic distribution and frequency of a taurine Bos taurus and an indicine Bos indicus Y specific allele amongst sub-Saharan African cattle breeds. Mol Ecol 2000;9:387-96.

14. Schoeman SJ. Review: Recent research into the production potential of indigenous cattle with specific reference to Sanga. S Afr J Anim Sci 1989;19:55-61.

15. Halimani TE, Muchadeyi FC, Chimonyo M, Dzama K. Pig genetic resource conservation: The Southern African perspective. Ecol Econ 2010;69:944-51.

16. Mapiye C, Chimonyo M, Dzama K, Raats JG, Mapekula M. Opportunities for improving Nguni cattle production in the smallholder farming systems of South Africa. Livest Sci 2009;24:196-204.

17. Bessa, I, Pinheiro I, Matola M, et al. Genetic diversity and relationships among indigenous Mozambican cattle breeds. S Afr J Anim Sci 2009;39:1.

18. Hanotte O, Dessie T, Kemp S. Time to tap Africa's livestock genomes. Washington: Science 2010;328:1640-1.

19. Musemwa L, Mushunje A, Chimonyo M, Mapiye C. Low cattle market off-take rates in communal production systems of South Africa: Causes and mitigation strategies. J Sust Dev Afr 2010;12: 1520-39.

20. Mapiye C, Chimonyo M, Muchenje V, et al. Potential for valueaddition of Nguni cattle products in the communal areas of South Africa. Afr J Agric Res 2007;2:488-95.

21. Musemwa L, Mushunje A, Chimonyo M, et al. Nguni cattle marketing constraints and opportunities in the communal areas of South Africa: review. Afr J Agric Res 2008;3:239-45.

22. Shackleton CM, Shackleton SE, Netshiluvhi TR, Mathabela FR, Phiri C. The direct use value of goods and services attributed to cattle and goats in the Sand River Catchment, Bushbuckridge. No. ENVP-C 99003, CSIR, Pretoria; 1999.

23. Dovie DBK, Shackleton CM, Witkowski ETF. Valuation of communal area livestock benefits, rural livelihoods and related policy issues. Land Use Policy 2006;23:260-71.

24. Simela L, Montshwe BD, Mahanjana AM, Tshuwa MP. The livestock production environment in the South African smallholder sector. 
New challenges for the animal science industries. SASAS 41st Congress Abstracts; 2006. p. 66.

25. FAO. Marker assisted selection "Current status and future perspectives in crops, livestock, forestry and fish". Rome, Italy Food and Agricultural Organisation 2006 Sub-regional report on animal genetic resources: Southern Africa. Annex to the State of the World's Animal Genetic Resources for Food and Agriculture. Rome, Italy: FAO; 2007. p. 1-37.

26. Chimonyo M, Kusina NT, Hamudikuwanda H, Nyoni O. Reproductive performance and body weight changes in draught cows in a smallholder semi-arid farming area of Zimbabwe. Trop Anim Health Prod 2000;32:405-15.

27. Ejlertsen M, Poole J, Marshall K. Traditional breeding objectives and practices of goat, sheep and cattle smallholders in the Gambia and implications in relation to the design of breeding interventions. Trop Anim Health Prod 2012;45:219-29.

28. Chimonyo M, Kusina NT, Hamudikuwanda H, Nyoni O, Ncube I. Effects of dietary supplementation and work stress on ovarian activity in non-lactating Mashona cows in a smallholder farming area of Zimbabwe. Anim Sci 2000;70:317-23.

29. Peco B, Sánchez AM, Ázcarate FM. Abandonment in grazing systems: consequences for vegetation and soil. Agric Ecosyst Environ 2006; 113:284-94.

30. Aboud AA, Kisoyan PK, Said MY, et al. Natural resource management and biodiversity conservation in the drylands of eastern and central Africa. Entebbe, Uganda: ASARECA; 2012.

31. Huntsinger L, Sayre NF, Wulfhorst JD. Birds, beasts and bovines: three cases of pastoralism and wildlife in the USA. Pastoralism 2012;2:12.

32. García RR, Fraser MD, Celaya R, et al. Grazing land management and biodiversity in the Atlantic European heathlands: a review. Agroforest Syst 2013;87:19-43.

33. Fabre P, Guérin G, Bouquet PM. The management of natural areas by pastoralism. A French mediterranean example: the Merinos d'Arles in transhumance. Rambouillet, France: In: Proceedings of the 8th World Merino Conference, 2010.

34. Kugler K, Broxham E. The ecological value of free-ranging livestock. Safeguard for Agricultural Varieties in Europe, 2013.

35. FAO. The nature of ecosystem services provided by livestock species and breeds. Intergovernmental Technical Working Group on Animal Genetic Resources for Food and Agriculture, Eighth Session. Rome, Italy: FAO; 2014. pp. 26-8.

36. Hatfield P, Goosey H, Lenssen A, Blodgett S. Sheep grazing to manage crop residues, insects and weeds in northern plains grain and alfalfa systems. SARE. c2011. Available from: http://www.sare.org/LearningCenter/Fact-Sheets/National-SARE-Fact-Sheets/Sheep-Grazingto-Manage-Crop-Residues-Insects-and-Weeds-in-NorthernPlains-Grain-and-Alfalfa-Systems. c2011. Available from: www. sare.org/publications/factsheet/pdf/11AGI2011.pdf

37. Kugonza DR, Nabasirye M, Mpairwe D, Hanotte O, Okeyo AM. Productivity and morphology of Ankole cattle in three livestock production systems in Uganda. Anim Genet Res 2011;48:13-22.
38. Terefe E, Haile A, Mulatu W, Dessie T, Mwai O. Phenotypic characteristics and trypanosome prevalence of Mursi cattle breed in the Bodi and Mursi districts of South Omo Zone, Southwest Ethiopia. Trop Anim Health Prod 2015;47:485-93.

39. Mirkena T, Duguma G, Haile A, et al. Genetics of adaptation in domestic farm animals: a review. Livest Sci 2010;132:1-12.

40. Seifert GW, Hofmeyr JH, Meyer EHH. South African Stud Book and Livestock Improvement Association. Proceedings of the 2nd World. Congress on Sheep and Beef Cattle Breeding. Bloemfontein, Pretoria, South Africa: South African Stud Book and Livestock Improvement Association; 1984.

41. Shabtay A. Adaptive traits of indigenous cattle breeds: The Mediterranean Baladi as a case study. Meat Sci 2015;109:27-39.

42. Jonsson NN. The productivity effects of cattle tick (Boophilus microplus) infestation on cattle, with particular reference to Bos indicus cattle and their crosses. Vet Parasitol 2006;137:1-10.

43. Collins-Lusweti E. Performance of Nguni Afrikaner and Bonsmara cattle under drought conditions in the North West Province of Southern Africa. S Afr J Anim Sci 2000;30:33.

44. Otto F, Vilela F, Harun M, et al. Biochemical blood profile of Angoni cattle in Mozambique. Isr J Vet Med 2000;55:2000.

45. Schoeman SJ. Review: Recent research into the production potential of indigenous cattle with specific reference to Sanga. S Afr J Anim Sci 1989;19:55-61.

46. Strydom PE, Naude RT, Smith MF, et al. Relationships between production and product traits in subpopulations of Bonsmara and Nguni cattle. S Afr J Anim Sci 2001;31:181-94.

47. Muchenje V, Dzama K, Chimonyo M, Raats JG, Strydom PE. Tick susceptibility and its effects on growth performance and carcass Chimonyo characteristics of Nguni, Bonsmara and Angus steers raised on natural pasture. Animal 2008;2:298-304.

48. Marufu MC, Chimonyo M, Mapiye C, Dzama K. Tick loads in cattle raised on sweet and sour rangelands in the low-input farming areas of South Africa. Trop Anim Health Prod 2011;43:307-13.

49. Muchenje V, Dzama K, Chimonyo M, Raats JG, Strydom PE. Meat quality of Nguni, Bonsmara and Aberdeen Angus steers raised on natural pasture in the Eastern Cape, South Africa. Meat Sci 2008;79:20-8.

50. Nqeno N, Chimonyo M, Mapiye C. Farmers' perceptions of the causes of low reproductive performance in cows kept under lowinput communal production systems in South Africa. Trop Anim Health Prod 2011;43:315-21.

51. Mapekula M, Mapiye C, Chimonyo M. Changes in metabolites concentration in Nguni and crossbred calves on natural pasture. Asian-Australas J Anim Sci 2011;24:1569-76.

52. Ndlovu T, Chimonyo M, Muchenje V. Monthly changes in body condition scores and internal parasite prevalence in Nguni, Bonsmara and Angus steers raised on sweetveld. Trop Anim Health Prod 2009;41:1169-77.

53. Rony SA, Mondal MMH, Begun N, Islam MA, Affroze S. Epidemiology of ectoparasitic infestations in cattle at Bhawal Forest Area, Gazipur, Bangladesh. J Vet Med 2010;8:27-33. 
54. Davidi M. Tick control in tswana, simmental and brahma cattle by means of neem seed extracts (Azadirachta indica). Master's Dissertation. Pretoria, South Africa: University of Pretoria; 2006.

55. Gashaw A. Host preference and seasonal variation of tick (Amblyomma cohaerens Donitz, 1909) on naturally infested cattle in jimma zone, southwestern Ethiopia. J Agric Rural Dev Trop Subtrop 2005;106:49-57.

56. Olwoch JM, Reyers B, Engelbrecht FA, Erasmus BFN. Climate change and the tick-borne disease, Theileriosis (East Coast fever) in subSaharan Africa. J. Arid Environ 2008;72:108-20.

57. Smith ER, Parker DM. Tick communities at the expanding wildlife/ cattle interface in the Eastern Cape Province, South Africa: implications for Corridor disease. J S Afr Vet Assoc 2010;81:237-40.

58. Piper EK, Jonsson NN, Gondro C, et al. Immunological profiles of Bos taurus and Bos indicus cattle infested with the cattle tick, Rhipicephalus (Boophilus) microplus. Clin Vaccine Immunol 2009; 16:1074-86.

59. Scholtz MM, Spickett AM, Lombard PE, Enslin CB. The effect of tick infestation on the productivity of cows of three breeds of cattle. Onderstepoort J Vet Res 1991;58:71-4.

60. Marufu CM, Chimonyo M, Dzama K, Mapiye C. Seroprevalence of tick-borne diseases in smallholder cattle reared on sweet and sour rangelands in a semi-arid area of South Africa. Vet J 2010; 184:71-6.

61. Marufu MC, Chimonyo M, Mans BJ, Dzama K. Cutaneous hypersensitivity responses to Rhipicephalus tick larval antigens in presensitized cattle. Ticks Tick Borne Dis 2013;4:311-6.

62. Mapholi NO, Marufu MC, Maiwashe A, et al. Towards a genomics approach to tick (Acari: Ixodidae) control in cattle: a review. Ticks Tick Borne Dis 2014;5:475-83.

63. Mwai O, Hanotte O, Kwon YJ, Cho S. African indigenous cattle: unique genetic resources in a rapidly changing world. Asian-Australas. J. Anim. Sci 2015;28:911-21.

64. Almekinders CJM. Incentive measures for sustainable use and conservation of agrobiodiversity. Experiences and lessons from Southern Africa. Lusaka, Zambia: Proceedings of a Workshop, 2002. pp. 11-14.

65. Marufu MC, Dzama K, Chimonyo M. Cellular responses to Rhipicephalus microplus infestations in pre-sensitised cattle with differing phenotypes of infestation. Exp Appl Acarol 2014;62:241-52.

66. Andersson L, Georges M. Domestic-animal genomics: deciphering the genetics of complex traits. Nat Rev Genet 2004;5:202-12.

67. Latif AA. Sustainable control methods for ticks and tick-borne diseases in Africa. In: Kategile JA, Mubi S, editors. Future of Livestock Industries in East and Southern Africa: Proceedings of the Workshop. Addis Ababa, Ethiopia: International Livestock Centre for Africa; 1993. pp. 119-22.

68. Ndlovu DN, Makaya PV, Penzhorn BL. Tick infestation, udder and teat damage in selected cattle herds of Matebeleland South, Zimbabwe. Onderstepoort J Vet Res 2009;76:235-48.

69. Dimander SO, Hoglund J, Sporndly E, Waller PJ. The impact of internal parasites on the productivity of young cattle organically reared on semi-natural pasture in Sweden. Vet Parasitol 2000;90: 271-84.

70. Vercruysse J, Claerebout E. Treatment vs. nontreatment of helminth infections in cattle: defining the thresholds. Vet Parasitol 2001;98: 195-214.

71. Coles GC. Anthelmintic resistance-looking to the future: a UK perspective. Res Vet Sci 2005;78:99-108.

72. Chimonyo M, Kusina NT, Hamudikuwanda H, Ncube I. Changes in stress-related plasma metabolite concentrations in working Mashona cows on dietary supplementation. Livest Prod Sci 2002; 73:165-73.

73. Dreyer K, Fourie LJ, Kok DJ. Assessment of cattle owner's perceptions and expectations, and identification of constraints on production in a peri-urban, resource-poor environment. Onderstepoort J Vet Res 1999;66:95-102.

74. Gasbarre LC, Leighton EA, Sonstergard T. Role of the bovine immune system and genome in resistance to gastrointestinal nematodes. Vet Parasitol 2001;98:51-64.

75. Xhomfulana V, Mapiye C, Chimonyo M, Marufu MC. Supplements containing Acacia karroo foliage reduce nematode burdens in Nguni and crossbred cattle. Anim Prod Sci 2009;49:646-53.

76. Marufu MC, Mapiye C, Chimonyo M. Nematode worm burdens in Nguni cattle on communal rangelands in a semi-arid area of South Africa. Res Opin Anim Vet Sci 2011;1:360-7.

77. Naessens, J. Bovine trypanotolerance: A natural ability to prevent severe anaemia and haemophagocytic syndrome? Int J Parasitol 2006;36:521-8.

78. Noyes H, Brass A, Obara I, et al. Genetic and expression analysis of cattle identifies candidate genes in pathways responding to Trypanosoma congolense infection. Proc Natl Acad Sci USA. 2011; 108:9304-9.

79. O'Gorman GM, Park SD, Hill EW, et al. Transcriptional profiling of cattle infected with Trypanosoma congolense highlights gene expression signatures underlying trypanotolerance and trypanosusceptibility. BMC Genomics 2009;10:207.

80. Stijlemans B, Vankrunkelsven A, Brys L, et al. Scrutinizing the mechanisms underlying the induction of anemia of inflammation through GPI mediated modulation of macrophage activation in a model of African trypanosomiasis. Microbes Infect 2010;12: 389-99.

81. Gardener GE, McIntyre BL, Tudor GD, Pethick DW. The impact of nutrition on bovine muscle glycogen metabolism following exercise. Aust J Agric Res 2001;52:461-70.

82. Baublits RT, Brown AH Jr, Pohlman FW, et al. Carcass and beef colour characteristics of three biological types of cattle grazing cool-season forages supplemented with soyhulls. Meat Sci 2004; 68:297-303.

83. Thornton PK, van de Steeg J, Notenbaert A, Herrero M. The impacts of climate change on livestock and livestock systems in developing countries: A review of what we know and what we need to know. Agric Syst 2009;101:113-27.

84. Scholtz MM, McManus C, Leeuw KJ, et al. The effect of global 
warming on beef production in developing countries of the southern hemisphere. Nat Sci 2013;5:106-19.

85. Nardone A, Ronchi B, Lacetera N, Ranieri MS, Bernabucci U. Effects of climate changes on animal production and sustainability of livestock systems. Livest Sci 2010;130:57-69.

86. Gregory NG. How climatic changes could affect meat quality. Food Res Int 2010;43:1866-73.

87. Bayer W, Deep frozen? Alive and kicking? Different approaches to the conservation of farm animal diversity. GIZ; 2006.

88. Holt WV, Pickard AR. Role of reproductive technologies and genetic resource banks in animal conservation. Rev Reprod 1999;4:14350.

89. Rege JEO, Gibson JP. Animal genetic resources and economic development: issues in relation to economic valuation. Ecol Econ 2003;45:319-30.

90. FAO. World watch list for domestic animal diversity. 3rd edn. Rome, Italy: FAO; 2000.

91. Gandini GC, Oldenbroek JK. Strategies for moving from conservation to utilisation. In: Oldenbroek JK, editor. Utilisation and Conservation of Farm Animal Genetic Resources. The Netherlands: Wageningen Academic Publishers; 2007. p. 29-54.

92. Pattison J, Drucker AG, Anderson S. The cost of conserving livestock diversity? Incentive measures and conservation options for maintaining indigenous Pelón pigs in Yucatan, Mexico. Trop Anim Health Prod 2007;39:339-53.

93. Oldenbroek JK. Introduction. In: Oldenbroek JK, editor. Utilisation and conservation of farm animal genetic resources. The Netherlands: Wageningen Academic Publishers; 2007. p. 13-27.

94. Tada O. Indigenous cattle breeds of Zimbabwe: How applicable are the conservation strategies! UNISWA J. Agric 2011;15:110-6.

95. Tada O, Muchenje V, Dzama K. Reproductive efficiency and herd demography of Nguni cattle in village-owned and group-owned enterprises under low-input communal production systems. Trop Anim Health Prod 2013;45:1321-9.

96. Cromwell E. Incentive measures at the farmers' level to enhance use and conservation of agricultural biodiversity. In: Incentive Measures for Sustainable Use and Conservation of Agrobiodiversity. Experiences and Lessons from Southern Africa. Lusaka, Zambia: Proceedings of a Workshop; 2002. pp. 24-34.

97. Ramsay K. Marketing rare breeds in Sub-Saharan Africa. In: Incentive Measures for Sustainable Use and Conservation of Agrobiodiversity. Experiences and Lessons from Southern Africa. Lusaka, Zambia: Proceedings of a Workshop; 2002 p. 61-68.

98. Tada O, Muchenje V, Madzimure J, Dzama K. Determination of economic weights for breeding traits in indigenous Nguni cattle under in-situ conservation. Livest Sci 2013;155:8-16.

99. Khombe CT. Crossbreeding Beef Cattle. Cattle Producers Association Harare, Zimbabwe. c1998 [Cited 2015 Jan]. Available from: http:// agtr.ilri.cgiar.org/agtrweb/index2.php?option=com_content\&do_ pdf $=1$ \&id $=82$

100. Muchenje V, Chimedza-Graham R, Sikhosana JLN, et al. Milk yield of Jersey $\times$ Nguni and Jersey $\times$ Tuli F1 and F2 cows reared under smallholder farming conditions. S Afr J Anim Sci 2007;8: 7-10.

101.Barret JC. The economic role of cattle in communal farming systems in Zimbabwe. London, UK: Overseas Development Institute; 1992.

102.Blackburn HD. The national animal germplasm program: challenges and opportunities for poultry genetic resources. Poult Sci 2006; 85:210-5.

103.Woelders H, Zuidberg CA, Hienstra SJ. Animal genetic resources conservation in the Netherlands and Europe: poultry perspective. Poult Sci 2006;85:216-22.

104.Tada O, Muchenje V, Dzama K. Monetary value of Nguni cattle and socio-economic profiles of farmers in the low-input communal production system of Eastern Cape Province, South Africa. Afr J Bus Manag 2012; 6:11304-11.

105.Barker JSF. Conservation and management of genetic diversity: a domestic animal perspective. Can J For Res 2001;31:588-95.

106. Mapiye C, Chimonyo M, Dzama K. Seasonal dynamics, production potential and efficiency of cattle in the sweet and sour communal rangelands in South Africa. J Arid Environ 2009;73:529-36.

107.Bester J, Matjuda LM, Rust JM, Fourie HJ. The Nguni: A case study. Irene, South Africa: Animal Improvement Institute; 2003. pp. 1-36.

108.DRDAR (Department of Rural Development and Agrarian Reform). Eastern Cape Province, South Africa: Department of Rural Development and Agrarian Reform; 2011.

109.Raats JG, Magadlela AM, Fraser GCG, Hugo A. Re-introducing Nguni Nucleus Herds in 100 Smallholder Villages of the Eastern Cape Province. A proposed co-operative project between the University of Fort Hare. East London, South Africa: Agricultural and Development Research Institute (ARDRI) and the Eastern Cape Department of Agriculture and the Kellogg Foundation; 2004.

110.Minjauw B, McLeod A. Tick-borne diseases and poverty. The impact of ticks and tick-borne diseases on the livelihood of smallscale and marginal livestock owners in India and Eastern and Southern Africa. Research report, DFID Animal Health Programme. Edinburgh, UK: Centre for Tropical Veterinary Medicine, University of Edinburgh; 2003.

111.Faku N. Reintroduction of Nguni cattle breed in the rural communities of the Eastern Cape, South Africa. M.Sc. Thesis. Wageningen, The Netherlands: Wageningen University; 2009.

112.Industrial Development Cooperation. IDC Newsletter. c2010 [Cited 2015 Aug] Available from: http://www.idc.co.za/access/ includes/htmlnewsletter/pdf/full_newletter;2010.pdf

113.Nguni KZN. KwaZulu Natal Nguni Cattle Club; c2012 [Cited 2015 Aug]. Available from: http://www.kznnguni.co.za/

114.Scarpa R, Drucker AG, Anderson S, et al. Valuing genetic resources in peasant economies: the case of 'hairless' creole pigs in Yucatan. Ecol Econ 2003;45:427-43.

115.Drucker AG, Gomez V, Anderson S. The economic valuation of farm animal genetic resources: a survey of available methods. Ecol Econ 2001;36:1-18.

116.Zander KK. Modelling the value of farm animal genetic resources 
- facilitating priority setting for the conservation of cattle in East Africa. PhD Thesis. Bonn, Germany: University of Bonn; 2006.

117.Hesterberg UW, Bagnall R, Perrett K, Horner R, Gummow B. A questionnaire survey of perceptions and preventive measures related to animal health amongst cattle owners of rural communities in KwaZulu-Natal, South Africa. J S Afr Vet Assoc 2007;78:205-8.

118.Tada O, Muchenje V, Dzama K. Effective population size and inbreeding rate of indigenous Nguni cattle under in-situ conservation in the low-input communal production system. S Afr J Anim Sci 2013;43:137-42.

119. Masika PJ, Mafu JV. Aspects of goat farming in the communal farming systems of the central Eastern Cape, South Africa. Small Rumin Res 2004;52:161-4.

120. Masikati, P. Improving the water productivity of integrated croplivestock systems in the semi-arid tropics of Zimbabwe: an exante analysis using simulation modeling. [Cited 2011] Available from: http://www.zef.de/fileadmin/webfiles/downloads/zefc_ ecology_development/eds_78_masikati_text.pdf

121.Andersen HJ, Oksbjerg N, Young JF, Therkildsen M. Feeding and meat quality - a future approach. Meat Sci 2005;70:543-54.

122.Katiyatiya CLF, Muchenje V, Mushunje A. Farmer's perceptions and knowledge of cattle adaptation to heat stress and tick resistance in the Eastern Cape, South Africa. Asian-Australas J Anim Sci 2014;27:1663-70.

123.Mapfumo L, Muchenje V. Comparative changes in monthly blood urea nitrogen, total protein concentrations, and body condition scores of Nguni cows and heifers raised on sweetveld. S Afr J Anim Sci 2015;45:96-103.

124.Van Soest PJ. Comparison of two different equations for predicting digestibility from cell contents, cell wall constituents and lignin content of ADF. J Dairy Sci 1995;48:815-23.

125. Mapiye C, Chimonyo M, Marufu C, Dzama K. Seasonal changes in energy-related blood metabolites and mineral profiles of Nguni and crossbred cattle on communal rangelands in the Eastern Cape, South Africa. Asian-Australas J Anim Sci 2010;23:708-18.

126. Mapiye C, Chimonyo M, Dzama K, Marufu MC. Protein status of indigenous Nguni and crossbred cattle in the semi-arid communal rangelands in South Africa. Asian-Australas J Anim Sci 2010;23: 213-25.

127.Adachi K, Kawano H, Tsuno K, et al. Values of the serum components in Japanese black beef steers at farms with high productivity and low frequencies of disease and death in Miyazaki Prefecture. J Vet Med Sci 1997;59:873-7.

128.Chawatama S, Mutisi C, Mupawaenda AC. The socio-economic status of smallholder livestock production in Zimbabwe: a diagnostic study. Livest Res Rural Dev 2005;17:988-1003.

129.Ngongoni TN, Mapiye C, Mwale M, Mupeta B. Factors affecting milk production in the smallholder dairy sector of Zimbabwe. Livest Res Rural Dev 2006;18:Article \#72.

130.Homann S, van Rooyen A. Unexploited agricultural growth: The case of crop-livestock production systems in Zimbabwe. Bulawayo, Zimbabwe: Proceedings of the AAAE Conference; 2007. pp. 503-6.
131.Mavedzenge BZ, Mahenehene J, Murimbarimba F, et al. Changes in the ivestock sector in Zimbabwe following land reform: The case of Masvingo Province; 2006. [Cited 2015 May] Available from: www.lalr.org.za

132. Changadeya W, Ambali AJD, Nyirenda JC, Chagunda MGG, Kaunda E. Genetic diversity and population structure of Malawi Zebu cattle. Int J Phys Soc Sci 2012;2:59-81.

133. Mashoko E, Muchenje V, Ndlovu T, et al. Beef cattle production in a peri-urban area of Zimbabwe. J Sust Dev Afr 2007;9:121-32.

134.Gwaze FR, Chimonyo M, Dzama K. Smallholder goat production in Southern Africa: a review. Trop Anim Health Prod 2009;41: 1157-68.

135.Gil M, Serra X, Gispert M, et al. The effect of beef-production systems on the myosin heavy chain 1, the biochemical characteristics and the colour variables of Longissimus thoracis from seven Spanish beef cattle breeds. Meat Sci 2001;58:181-8.

136.FAO. Mixed crop-livestock farming: A review of traditional technologies based on literature and field experience. Traditional technologies for animal production, Chapter 5; Rome, Italy: FAO; 2001.

137.Matlebyane MM, Ngambi JWW, Aregheore EM. Relationships between chemical composition and in vitro digestibility of some common forage species used for ruminant livestock production in three chief areas of Capricorn Region, Limpopo Province, South Africa. Res J Agric Biol Sci 2009;5:138-49.

138.Van Rooyen AF. Livestock development in Southern Africa: Future research and investment priorities. Pretoria, South Africa: International Crop Research Institute for Semi Arid Tropics (ICRISAT); 2007.

139.Ainslie A, Kepe T, Ntsebeza L, Ntshona Z, Turner S. Cattle ownership and production in the smallholder areas of the Eastern Cape, South Africa. Research report, Western Cape, South Africa: University of the Western Cape, South Africa; 2002.

140.Winter B. Partners in research for development: from farm to market: South African cattle partnerships. Partners magazine; 20078-13. [Cited 2015 Dec] Available from: http://www.aciar.gov.au/publi cation/term/36

141. Mueller JP, Rischkowsky B, Haile A, et al. Community-based livestock breeding programmes: essentials and examples. J Anim Breed Genet 2014;132:155-68.

142.Nqeno N, Chimonyo M, Mapiye C, Marufu MC. Ovarian activity, conception and pregnancy patterns of cows in the semiarid communal rangelands in the Eastern Cape Province of South Africa. Anim Reprod Sci 2010;118:140-7.

143.Nguni Cattle Breeders Society. Nguni 201125 Years - Breed from the past for the future. Bloemfontein, South Africa: Nguni Cattle Breeders Society; 2011. p. 29-34.

144.Ligda Ch, Georgoudis A. Defining the breeding objectives for small populations. Kutna Hora, Czech Republic: Workshop: European Livestock Breeds Ark and Rescue Net (ELBARN); 2008.

145.Kahi AK, Barwick SA, Graser HU. Economic evaluation of Hereford cattle breeding schemes incorporating direct and indirect measures of feed intake. Aust J Agric Res 2003;54:1039-55. 
146.Roessler R, Drucker AG, Scarpa R, et al. Using choice experiments to assess smallholder farmers' preferences for pig breeding traits in different production systems in North-West Vietnam. Ecol Econ 2008;66:184-92.

147.Scholtz MM, Theunissen A. The use of indigenous cattle in terminal cross-breeding to improve beef cattle production in Sub-Saharan Africa. Anim Genet Resour 2010;46:33-9.

148. Wollny CBA. The need to conserve farm animal genetic resources in Africa: should policy makers be concerned? Ecol. Econ 2003; 45:341-51.

149. Mapiye C, Mwale M, Mupangwa JF, et al. A research review of village chicken production constraints and opportunities in Zimbabwe. Asian-Australas J Anim Sci 2008;21:1680-88.

150.Tada O, Muchenje V, Dzama K. Preferential traits for breeding Nguni cattle in low-input in-situ conservation production system. Springerplus 2013;2:195.

151.Kimaro WH, Mukandiwa L, Mario EZJ. Towards improving agricultural extension service delivery in the SADC region. Dar es Salaam, Tanzania: In: Proceedings of the Workshop on Information Sharing among Extension Players in the SADC Region; 2010. p. 26-28.

152.Devendra C, Thomas D, Jabbar M, Zerbini E. Improvement of Livestock Production in Crop-Animal Systems in Agro-Ecological Zones of South Asia. Nairobi, Kenya: International Livestock Research Institute; 2000.

153.Toro MA, Villanueva B, Fernández J. Genomics applied to management strategies in conservation programmes. Livest Sci 2014; 166:48-53.

154.Meuwissen T, Hayes B, Goddard M. Accelerating improvement of livestock with genomic selection. Annu Rev Anim Biosci 2013; 1:221-37.

155.Mpofu N. Comparison of indigenous and foreign cattle for beef production at Matopos Research Station in Zimbabwe. ZaBelo Livestock Consultancy, Zimbabwe. c2002 [Cited 2015 Oct]. Available from: http://agtr.ilri.cgiar.org/Casestudy/case-mpofu-1/casestudyMpofu-matchingenv-1.htm

156.Keith J. The impact of cattle/beef prices on incomes and poverty in Botswana. Gaborone, Botswana: Report submitted to USAID/ Southern Africa; 2007.

157.Dzanja J, Kapondamgaga P, Tchale H. Value chain analysis of beef in central and southern malawi. Int J Bus Soc Sci 2013;4:92-102.

158.Sitoe T. Productive diversification. Southern Mozambique: Analysis of Horticultural Production in the Green Belt of Maputo City; 2010.

159.Hangara GN, Teweldemedhin MY, Groenewald IB. Assessment on the constraints of cattle supply chain management in Namibia. Afr J Agric Res 2012;7:4876-84.

160.Meissner HH, Scholtz MM, Palmer AR. Sustainability of the South African livestock sector towards 2050 Part 1: worth and impact of the sector. S Afr J Anim Sci 2013;43:282-97.

161.Tembo G, Goma FY, Tembo A, Kabwe S. Productive potential, market access and smallholder livestock production: evidence from southern Zambia. Res Appl Econ 2014;6:132-48.

162.Tuli Cattle Breeders Society of Zimbabwe. Gweru, Zimbabwe: Tuli. Modern press (pvt) Ltd;1995.

163.Kotze A, Harun M, Otto F, Van der Bank FH. Genetic relationships between three indigenous cattle breeds in Mozambique. S Afr J Anim Sci 2000;30:92-7.

164.Rechav Y, Kostrzewski MW, Els DA. Resistance of indigenous African cattle to the tick Amblyomma hebraeum. Exp Appl Acarol 1991;12:229-41.

165.Norval RAI, Sutherst RW, Kerr JD. Infestation of the Amblyomma hebraeum (Acari: Ixodidae) on different breeds of the cattle in Zimbabwe. Exp Appl Acarol 1996;20:223-30.

166.Frisch JE, O’Neill CJ. Comparative evaluation of beef cattle breeds of African European and Indian origins. 2. Resistance to cattle ticks and gastrointestinal nematodes. Anim Sci 1998;67:39-48.

167.Katiyatiya CLF, Muchenje V, Mushunje A. Seasonal variation in coat characteristics, tick loads, cortisol levels, some physiological parameters and temperature humidity index on Nguni cows raised in low- and high-input farms. Int J Biometeriol 2015;59:733.

168.Masika PJ, Afolayan AJ. Antimicrobial activity of some plants used for the treatment of livestock disease in the Eastern Cape, South Africa. J Ethnopharmacol 2002;83:129-34. 